\title{
Korkea-asteen koulutuksen yhteiskunnallisesta ja yksilöllisestä merkityksestä *)
}

\begin{abstract}
Heiskanen, Ilkka. 1982. Korkea-asteen koulutuksen yhteiskunnallisesta ja yksilöllisestä merkityksestä. Aikuiskasvatus 2, 3, 85-87. - Artikkelissa tarkastellaan yliopistojen tehtäviä informaatioyhteiskunnassa. Kirjoittaja näkee korkeakoulujen ja korkeaasteen koulutettujen yhteiskunnalliseksi tehtäväksi toimia tiedollisen redundanssin ja vastaälyn tuottajina, tallentajina ja käytäntöön siirtäjinä. Käyttämiensä käsitteiden pohjalta kirjoittaja näkee yliopistoilla olevan merkittävä tehtävä yhteiskunnallisen kehityksen osatekijänä.
\end{abstract}

\section{Kaksi linjaa: kulttuuri ja tieteellis-tekninen tieto}

Korkea-asteen koulutusta on perusteltu tai voisi jopa sanoa myyty - kahden argumentaatiolinjan avulla. Ensimmäinen näistä linjoista puhuu kauniisti kulttuurista, toinen tieteellis-teknisestä tiedosta. Ensimmäinen linja korostaa yliopistojen ja korkeakoulujen merkitystä kansallisen kulttuurin ylläpitäjinä ja lippulaivoina, toinen taas korostaa tieteellistä tietoa taloudellisen ja yhteiskunnallisen kehityksen perusvoimana, yhteiskunnallisen kehityksen ja muutoksen demonisena alkulähteenä. Ensimmäinen linja lupaa korkea-asteen koulutetulle intellektuellin aseman ja siihen liittyvät palkinnot, toinen linja taas teknokraatin aseman ja siihen liittyvät palkinnot.

Nämä keskustelun kaksi linjaa voidaan jäljittää historiassa taaksepäin aina Wilhelm von Humboldtin yliopistomallin muotoutumiseen ja 19. vuosisadan puolivälin preussilaiseen koulukeskusteluun. Meillä näiden kahden ar-

*) Artikkeli perustuu Akavan Korkea-asteen tăy-dennyskoulutuspäivillă $17 .-18.5 .82$ pidettyyn esi-telmäăn. gumentaatiolinjan välistä rajaa pyrki selvittämään ja ylittämään mm. Eino Kaila, joka 1940 julkaistussa kirjasessaan '’Kolmesataa vuotta suomalaista yliopistoelämää’' kirjoitti:

"Tästd asiasta on kuitenkin esitetty toisenkinlaisia mielipiteitä, ja on paljon keskusteltu siitä, ei$k o ̈$ tieteellisten opintojen erikoistuminen ja keskittyminen jo ole mennyt liiankin pitkalle. Toisaalta on jo huomautettu, että korkeampi tieteellinen sivistys ei sisally vain siihen, etta muodollisesti hallitaan tiettyja tutkimusmenetelmia ja harjaannutaan kriittiseen tieteelliseen ajatustapaan, vaan etta lisäksi on saavutettava tietty henkisen näköpiirin avaruus ja kyky nähda erikoisseikkoja niiden suuremmissa yhteyksissä. Toisaalta taas on korostettu, että tieteellisen sivistyksen ytimena kuitenkin on harjaantuminen itse tieteelliseen tutkimustapaan, ja se saavutetaan jonkun tietyn aineiston perusteellisella $k a-$ sittelyllä eikä yleiskatsauksilla, jotka helposti jadvat pintapuolisiksi.",

Ja Kaila itse, kahden maailman ja kulttuurin kansalaisena, kysyy vastaamatta:

"Sata vuotta sitten tuli filosofiankandidaatin tietäa jotakin vähäista koko oman aikansa hengen- ja luonnontieteellisesta tutkimuksesta. Oli muutos, joka tässä on tapahtunut, korkeammalle tieteelliselle sivistykselle lopulta edullinen tai vahingollinen, valtava se ainakin on ja kehityksen suunta on selva."” 
Keskustelu korkea-asteen koulutuksen kulttuuri- ja tieteellis-teknisistä funktioista elpyi maassamme korkeakoulujen tutkinnonuudistustaistelujen myötä. Uudistuksen alkuperäinen pyhä kirja, FYTT-mietintö, lähti kyllä liikkeelle tieteellisen tiedon yleissivistävästä merkityksestä, mutta uskoi lujasti pyhään kolmiyhteyteen: yksi tiede, yksi teknologia, yksi didaktiikka. Niinpä tutkinnonuudistuksen viimeiset kamppailut käytiin jälleen vanhalla linjalla: kulttuuriyliopisto versus teknokraattinen yliopisto.

Olisi tietysti helppoa pujahtaa - Eino Kailan tapaan - molempien linjojen välistä ja sanoa, että korkea-asteen koulutus antaa yhteiskunnalle ja yksilöille sekä kulttuurilinjan että tieteellis-teknisen linjan hyötyjä. Ja että se tuottaa yhteiskunnalle kulttuuria ja knowhow'ta, yksilöille yleistä älyllistä kapasiteettia ja nykyyhteiskunnan vaatimia tieteellis-teknisiä valmiuksia. Ja että kaikkeen tieteellistekniseen suuntaan erikoistuneeseen koulutukseen on liitettävä kulttuurialueitten tuntemusta lisäävää koulutusta ja kaikkeen humanistiseen koulutukseen on lisättävä tutustumista luonnontieteellisen ja teknologisen ajattelun viimeisiin saavutuksiin. Tai että tällainen riittävä, ristiinmenevä sivistäminen on saatava aikaan jo ennen korkeakouluopintojen alkamista, peruskoulu-, opisto- ja lukioasteilla.

Pyrin seuraavassa välttämään tätä kompromissia ja alkeellista yhteensovittamisratkaisua. Pyrin myös osoittamaan, miten pitemmälle menevät ratkaisut joutuvat nojaamaan täydennyskoulutusajatteluun - muodossa tai toisessa. Perustan ajatukseni eräille viimeaikaisille tietoa, tietämystä ja älykkyyttä koskeville tutkimuksille. Useimmat näistä tutkimuksista niistä tutkimussuunnista, joita ne edustavat ovat kriittisiä niin nyky-yhteiskuntaa kuin sen käyttämää tietoa ja sen tietovarantoja kohtaan. Pyrin kuitenkin kääntämään niiden johtopäätöksiä teknokraattiselle kielelle. Tällöin tarkasteluni keskeisiksi käsitteiksi nousevat "tiedollinen redundanssi" ja "vastaäly".

\section{Vaihtoehtoistieto ja vastaäly}

Voin aloittaa vanhalla kliseellä, että elämme informaatioyhteiskunnassa. Huomattavasti pienempi klisee on todeta, ettei informaatio ole älykkyyttä - ja että informaatio saattaa olla jopa älykkyyden vastaista. Jälleen informaation mahdollisesta "älykkyyden vastaisuudesta" on paljon puhuttu, kun on ruodittu tarpeetonta informaatiota, soveltamiskelvotonta informaatiota ja informaatiotulvaa. En tarkoi- ta näitä analyysilinjoja puhuessani informaation "älykkyyden vastaisuudesta". Tarkoitan sitä, että tietyn lajin informaation hankkimisesta ja käytöstä voi tulla peli, joka sitoo peliin osallistujia ja estää heitä toimimasta älykkäästi. Älykkyyttä taas on se, että osataan irtaantua vanhan pelin informaatiopremisseistä ja alkaa uusi peli uuden informaatiotyypin turvin. Älykkäillä yksilöillä, yhteisöillä ja yhteiskunnilla on siis tiedollista redundanssia, vaihtoehtoistietoa - tai pikemminkin vaihtoehtoiseen muotoon muokattua tietoa ja kykyä tällaisen vaihtoehtoistiedon muokkaamiseen. 'Vastaaly" on taas tiedollista redundanssia suppeampi käsite. Tarkoitan sillä kykyä analysoida yhteiskunnan informaatiopelejä ja niissä pelaavia yksiköitä ja paljastaa pelin todelliset ominaisuudet - ja myös sen heikkoudet vaihtoehtoispelien aloittamisen ja läpiviennin kannalta.

Otetaan yksinkertainen ja tuttu esimerkki. Japanin taloudellinen menestys perustuu japanilaisen yhteiskunnan ja japanilaisten yritysten tiedolliseen redundanssiin ja vastaälyyn suhteessa länsimaiset yhteiskunnat ja yritykset. Voitammeko mitään, jos jäljittelemme japanilaisia? Tuskin. Jätän muut vaihtoehdot lukijoiden pohdittavaksi ja palaan korkea-asteen koulutuksen pariin.

\section{Haasteet korkea-asteen ope- tukselle}

Edellä esitetystä on yksinkertaista palata puhumaan korkea-asteen koulutuksen yhteiskunnallisesta ja yksilöllisestä merkityksestä. Voidaan näet väittää, että yliopistojen ja korkeakoulujen tehtävänä on nimenomaan tuottaa pelkän informaation rinnalla ja sen yli - niin yksilöille kuin yhteiskunnallekin tiedollista redundanssia ja vastaälyä. Tätähän edellä lukemani Kaila-sitaatti tapaili puhuessaan "'henkisen näköpiirin avaruudesta"' ja "'kyvystä nähdä erikoisseikkoja niiden suuremmissa yhteyksissä."

Edellä esitetty ajatus tuntuu yksinkertaiselta ja selvästi ja itse asiassa sitä on usein sovellettu yliopistojen ja korkeakoulujen merkitystä eriteltäessä - joskin yleensä idealistisemmassa muodossa kuin mihin itse olen yllä sen formuloinut. Siinä on kuitenkin yksi selvä heikkous. Nyky-yhteiskunnan informaatiopelit pelataan yliopistojen ja korkeakoulujen ulkopuolella. Tiede ja korkea-asteen opetus ovat valitettavan usein tietämättömiä näiden pelien luonteesta. Ne voivat tuottaa tiedollista redundanssia, mutta ne ovat kykenemättömiä vastaäly-toimintaan. Tästä johtuen niiden 
tuottama tiedollinen redundanssi on usein kohdentamatonta ja tuhlaantuvaa. Voidaan kysyä millä keinoilla sitä voidaan paremmin kohentaa ja sen tuottoa tehostaa.

Kysymykseen näyttää olevan kahta lajia vas-tauksia. Ensiksikin voidaan tietysti ajatella, et-tä korkea-asteen opetukseen sisällỳtetään tie-toa yhteiskunnan informaatiopeleistä, jolloin korkea-asteen koulutetut ovat valmiimpia vie-mään läpi omaa itsenäistä ajatteluaan ja toimi-maan tiedollisen redundanssin käytäntöön siirtäjinä. Tätähän on osin tapailtu tutkinnonuudistuksen yleisopintojen ja eräiden syventävien opintojen korostamalla "yhteiskunnan tunte-muksella". Tutkinnonuudistuksen lähes täy-dellinen epäonnistuminen näiltä osin osoittaa tämän strategian vaikeuden. Jos sitä halutaan käyttää, tarvitaan uutta systemaattista vastaälytutkimusta ja sille perustuvaa opetusta.

Toinen mahdollisuus on, että korkea-asteen koulutettavat ja koulutetut matkaavat useammin kuin vain kerran opinahjon ja käytännön työelämän välisen matkan. Tällöin he käytännössä oppivat sen informaatiopelit ja tulevat taas korkeakouluihin ja yliopistoihin noutamaan tiedollista redundanssia, jonka he sitten siirtävät käytännön toimintaan. Tässä strategiassa nousee keskeiseksi akateemisen tutkimuk- sen ja käytännön väliset yhteistyöapurahat, harjoittelu ja taydennyskoulutus. Kaikkiin näihin on opetusministeriön toimesta kiinnitetty kiitettävästi huomiota viime vuosina. Vai-keutena on kuitenkin saada yliopistoja, kor-keakouluja ja niiden opettajia irti vakiintu-neista akateemisesti kuvioista siinä määrin, et-tä he vakavasti paneutuisivat näiden kolmen välineen kehittämiseen. Ilman tutkijain ja aka-teemisten opettajain panosta tiedollinen re-dundanssi ei kyllä liiku esimerkiksi täydennys-koulutuksen kautta.

Uskorı itse, että yliopistojen, korkeakoulujen ja korkea-asteen koulutettujen eräs keskeisin merkitys yhteiskunnassa on toimia edellä luonnostelemallani tavalla tiedollisen redundanssin ja vastaälyn tuottajina, tallentajina ja käytäntöön siirtäjinä. Tiedän myös omista tutkija- ja opettajakokemuksistani, että ne todella toimivat näissä funktioissa. Uskon myös, että kansakunnan etu vaatii näiden funktioiden voimistamista. Kokonaan toinen seikka sitten on, missä määrin yhteiskunnan päätöksentekijät ja vallanpitäjät todella haluavat tiedollista redundanssia ja vastaälyä. Molemmilla on näet heidän valta-asemaansa heikentäviä vaikutuksia. 